\title{
УЧЕТ ПРОДВИЖЕНИЯ ВНК ПРИ ПОСТРОЕНИИ ГЕОЛОГИЧЕСКОЙ МОДЕЛИ МЕСТОРОЖДЕНИЙ НА ПОЗДНЕЙ СТАДИИ РАЗРАБОТКИ (НА ПРИМЕРЕ ВЯТСКОЙ ПЛОЩАДИ АРЛАНСКОГО МЕСТОРОЖДЕНИЯ).
}

Будкин К.Д., Зорькина В.Я. (OOO «HTI( РуссНефть»)

В 2006 году была построена модель Вятской плотади Арланского месторождения нефти по $124 \mathrm{l}$ скважине. В модели использовалось большое количество поправок по скважинам (657скважин) и высокое значение КИН 0,431, при принятом 0,429.

Было принято ретение перестрокть модель, используя ту же корреляцию с учетом продвижения ВНК. Продвижение ВНК устанавливалось в скважинах по данным результатов работы соседних ранее пробуренных, вскрывших ВНК ниже и к моменту бурения новой сильно обводнившихся, или находящихся поблизости нагнетательных скважин пробуренных ранее.

Одной из основных проблем стало определение начального положения ВНК. Ее решение осложнялось тем, что большинство скважин наклоннонаправленные (погрепности инклинометрии на месторождении достаточно велики), количество вертикальных скважин составило около $2 \%$ (18шт), бурение скважкин и их эксплуатация были не равномерными по площади: изначально разбуривалась сводовая часть (в большинстве залежей являющаяся ЧНЗ), позже периферийная (ВНЗ), ВНК к этому временк во многих залежах уже начинал подниматься.

На рис.1 представлено распределение ВНК в одной из залежей терригенного пласта CVI нижнекаменноугольных отложений. Распределение ассиметрично имеет 1 максимум на отметке -1193. Залежь вскрыта 109 скважинами, все вскрыли ВНК (залежь водоплавающая), среднее значение ВНК по скважинам составляет $-1191,38$ и отличается от максимума ввиду ассиметричности распределения. В исходной модели ВНК было принято по среднему значению на отметке- 1191 , все скважины с отклонением от этой величины считались негравильно промеренными инклинометром, и в них вводились потравки, общее количество которых по Вятской площади составило 657 из 1241 скважины.

Было проанализировано положение ВНК в скважинах, пробуренньх до 1978 года- начала заводнения. На гистограмме отмечается максимум распределения ВНК на абсолютной отметке -1193, который выделяется на фоне единичных отклонений в разные стороны, связанных, возможно, с погрешностями инклинометрии. На основании этого ВНК был принят на отметке -1193 м.

ВНК, вскрытый ниже этой отметки, считался погрешностью инклинометрии, вскрытый вышеанализировался на возможность продвижения. Был написан алгоритм, сопоставляющий дату бурения скважины, вскрытый в ней ВНК, дату бурения соседних скважин, налидие перфораций в них, их обводненность начальную и к моменту бурения новой скважкны. В результате выявлено продвижение ВНК в 30 скважинах из 109 (продвижения в пределах 1 м не рассматривались). Изменение положения
ВНК за счет его продвижения составило от 1 до $9,7 \mathrm{M}$, в среднем $4,4 \mathrm{M}$.

На рисунке 2 показана гистограмма распределения без учета скважин с продвижением ВНК. Полученное распределение симметрично и не противоредит нормальному, максимум находится на отметке $-1193 \mathrm{M}$, среднее значения выборки составляет $-1192.89 \mathrm{M}$.

В результате для залежи были введены поправкя за инклинометрию в 44 скважинах вместо 76 , согласно исходной модели без учета продвижения ВНК. В целом по площади удалось сократить количество поправок до 177 подвижек вместо 657 в исходной.

Изменение положения ВНК и учет его продвижения в скважинах привел к увеличению начальных геологических запасов на $22,8 \%$ по пласту CVI и снижению текущего КИН с 0,431 до 0,407 при принятом 0,429 .

Определение истинного начального положения ВНК на месторождениях на поздней стадии разработки является одной из наиболее сложных задач, правильное решение которьх позволяет наиболее точно оценить начальные геологические запасы и способствует построению адекватной геологической модели.

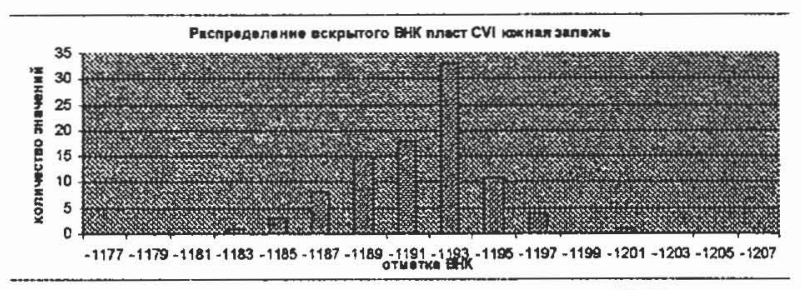

Рисунок 1 Распредетенне вскрытого ВНК пиаст CVI южная залежь

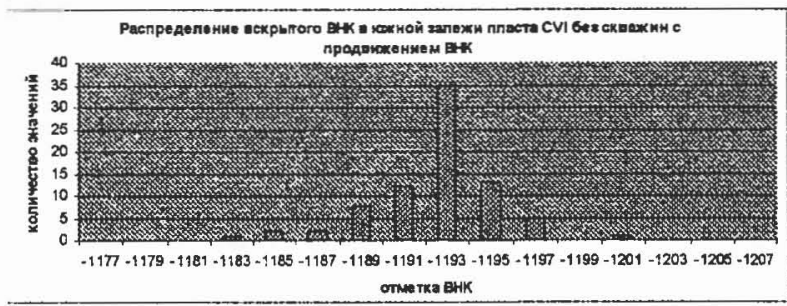

Рисунок 2 Распределение вскрытого ВНК в южной залежи пласта CVI без скважин с продвижением ВНК 